\title{
Kuantum Mekaniği, Sosyal Bilimler Felsefesi ve Coğrafya
}

\author{
Münür Bilgilia,b Mehmet Ali Toprak
}

\section{Özet}

Fizik biliminde meydana gelen gelişmeler, doğa bilimlerinin epistemolojisini etkilemiştir. Sosyal bilimler ve daha özelde coğrafya uzun dönem bilimsel alanda hakim konumda olan doğa bilimleri karşısında konumlanmaya çalışmıştır. Sosyal bilimler ve coğrafyanın kurumsallaşması 18. yüzyıla dayanmaktadır. Sosyal bilimlerin ve coğrafyanın, konuları ele alma biçiminde, bilimsel iddialarında ve yaklaşımlarında bu dönemde hakim olan doğa bilimleri felsefesi etkili olmuştur. 20. yüzyıl başlarında fizik biliminde meydana gelen değişmeler kuantum mekaniğinin gündeme gelmesine ve modern bilimin eleştirilmesi ve meşruiyetinin sarsılması ile sonuçlanmıştır. Kuantum mekaniğinin etkileri ve dönemin sosyal, ekonomik ve politik olayları bilimsel alanda paradigma dönüşümlerine yol açmıştır. Ortaya çıkan yeni durumda sosyal bilimler ve coğrafyanın felsefesinde değişimler yaşanmıştır. Bu dönemde sosyal bilimler ve coğrafya, modern doğa bilimlerinin meşruiyetinin sorgulandiğ ortamda gerçek bilgiye ulaşmanın farklı yollarını aramış ve çok paradigmalı bir döneme girmiştir. Bu çalışmanın temel amacı, dönemin sosyal, ekonomik ve politik gelişmelerinin yanı sıra kuantum mekaniğinin sosyal bilimler ve coğrafya üzerindeki etkilerini değerlendirmektir. Yapılan değerlendirmelere göre, kuantum mekaniği, sadece modern bilimin "bilimsellik" iddiasını sarsmakla kalmamış aynı zamanda bilimsel araştırmaların ön yargıyla yapıldı̆̆ını, "gerçeğin" kültürel faktörlere bağlı olduğunu, araştırmacının rolünün araştırmanın sonuçları üzerinde etkili ortaya koymuştur.
Anahtar Kelimeler

Modern Bilim Felsefesi

Kuantum Mekaniği

Sosyal Bilimler Felsefesi

Coğrafya Felsefesi

Makale Hakkında

Geliş Tarihi: 12.06.2018

Kabul Tarihi: 13.03.2020

Doi: 10.18026/cbayarsos.705019

\section{Quantum Mechanics, Philosophy of Social Sciences and Geography}

\begin{abstract}
Developments in physics have affected the epistemology of natural sciences. Social sciences, and more particularly geography, have long been trying to take position themselves by natural sciences, which dominate the scientific field for a long time. The institutionalization of social science and geography goes back to the 18th century. The philosophy of natural sciences, dominated by social sciences, and geography, in its way of dealing with issues, scientific claims and approaches, has been influential. The changes that took place in physics in the early 20th century resulted in the coming of quantum mechanics and the criticism of modern science and its loss of legitimacy. The effects of quantum mechanics and the social, economic and political events of the period have led to scientific paradigm shifts in the field. In the emerging new situation, there have been changes in the philosophy of social sciences and geography. In this period, social sciences and geography have entered a multi-paradigmatic period, seeking different ways of achieving real knowledge in an environment where the legitimacy of modern natural sciences is questioned. The main purpose of this paper is to evaluate the effects of the quantum mechanics on social sciences and geography in addition to the social, economic and political developments of the period. According to the evaluations, quantum mechanics revealed that not only did undermine modern science's "scientificnesss" claim but also set forth that scientific studies are prejudiced, and that "truth" depends on cultural factors, and the role of the researcher has an effect on research results.
\end{abstract}

Keywords

Modern Science Philosophy

Quantum Mechanics

Philosophy of Social Sciences

Philosophy of Geography

About Article

Received: 12.06.2018

Accepted: 13.03.2020

Doi: 10.18026/cbayarsos.705019 


\section{Giriş}

Sosyal bilimlerin kurumsallaşması, 19. yüzyıla dayandırılsa da sosyal olana ait bilgi, yüzyıllar boyunca düşünürlerin üzerinde durduğu önemli bir alan olmuştur. Sosyal bilimlerin ortaya çıkışı ve dönüşümünde modern bilimin etkisi yanında toplumdaki sosyal, ekonomik ve politik alt üst oluşlar etkili olmuştur. Fransız Devrimi ve sonrasında Avrupa'da yaşanan gelişmeler kitleleri anlama, yönetme ve yönlendirmeye yönelik sosyal bilgiye ihtiyaç doğurmuştur (Gulbenkian Komisyonu, 2009). 1970'lerde yaşanan toplumsal olaylar ise, epistemolojisini modern bilim felsefesi üzerinden inşa eden sosyal bilimlerin sorgulanmasına yol açmıştır. Modern bilimden hareketle epistemolojisi belirlenen sosyal bilimler felsefesinin dönüşmesi gerektiği ile ilgili vurgular bu dönemde yapılmaya başlanmıştır.

Doğa bilimlerinde meydana gelen teorik gelişmeler, sosyal bilimlerin ontolojisi ve epistemolojisinde dönüşümlere yol açmıştır. Sosyal bilimlerdeki bu dönüşümler, doğa bilimlerindeki bilimsel devrimlere referansla ele alınabilir. Daha çok fizik tarafından temsil edilen doğa bilimleri içinde öne çıkan ve bütün diğer disiplinleri de etkileyen bu devrimler Kuhncu anlamda üç başlık altında incelenebilir. Aristoteles/Ptolemy fiziği, Newton fiziği ve Kuantum mekaniği. 15. yüzyıl ortalarından itibaren Cusanus, Kopernik, Galileo, Kepler ve Newton gibi bilim insanlarının yaptıkları çalışmalar Aristoteles/Ptolemy fiziğinin eleştirilmesine yol açmıştır. Aristoteles/Ptolemy çizgisine göre evren, dünya merkezli, hiyerarşik, kusursuz ve sınırlıdır. Günlük yaşam deneyimleri ile uyumlu olan bu yaklaşım 15. ve 16. yüzyıla kadar etkisini korumuştur. Newton'un öncülük ettiği modern fiziğge göre ise evren, güneş merkezli, kusurlu, açı/sonsuz ve doğal bir ahenge sahiptir. Bu yeni evren modeli, eskinin teleolojik (evreni nedensellikten çok amaçlara göre açıklamak) açıklamaları yerine nedensellik ilkesini koymuştur. Teleolojik açıklamalarda "niçin" sorusu ön plana çıkarken, determinizmde "nasıl" sorusu ön plandadır. Modern fizik, insanın evren algısını ve onunla kurduğu ilişkiyi değiştirmiştir (Northrop, 1958). Bu değişim, insana kendisini merkezin dışında tahayyül etmeye ve evreni tamamen farklı bir açıdan gözlemlemeye olanak sağlamıştır (Skirbekk ve Gilje, 2014). Dönemin doğa bilimleri karşısında bir pozisyon edinmek için "sosyal fizik" tanımını kullanan sosyal bilimler doğa bilimleri gibi belirlenebilen, kesin ve evrensel bilgiye ulaşma vaadinde bulunmuştur. Sosyal bilimlerin ortaya çıkış aşamasında benimsediği bu mekanistik (makine paradigması) özellikleri o kadar güçlüdür ki sosyal bilimlerin çoğu hala bunun etkisi altındadır (Toffler, 1998: 13). Nüfus projeksiyonları, planlama kavramı ve kentsel birçok teori makine metaforu ve evrenin öngörülebilir olduğu fikrinin yansımaları olarak görülebilir.

20. yüzyıl başlarında fizikteki yeni gelişmeler yerleşik bilimsel pratiklere olan güveni sarmıştır. Fizik alanındaki bu gelişmelere paralel 1970'lerde dünyada yaşanan toplumsal hareketler de sosyal bilimlerin sorgulanmasına neden olmuştur. Bağımsızlık hareketleri, antiapartheid hareketler, ekolojik hareketler, feminist karşı çıkışlar ve şarkiyatçılık (oryantalizm) çalışmaları, bu sorgulamaların sonucu olarak ele alınabilir. Bu dönemde modern bilimin fordist, yapısalcı, pozitivist, evrensel ve akılcı gibi açıklama ve kavramlarının önüne 'post' eki getirilerek eleştirilmeye başlanmıştır. Epistemolojisini doğa bilimlerinin felsefesine dayandırmaya çalışan ve ona öykünen sosyal bilimler (Anlı, 2016), kuantum mekaniği ile meydana gelen açlımlardan etkilenerek yeni bir epistemoloji arayışı içine girmiştir. Bu çalışmanın temel amacı, sosyal bilimlerin çok paradigmalı döneme geçişini dönemin sosyal, ekonomik ve politik gelişmelerine ek olarak kuantum mekaniği üzerinden okumaktır. Kuantum fiziği, sosyal bilimler ve coğrafyanın felsefesini nasıl etkilemiştir? Fizikteki 
gelişmeler sosyal bilimler ve coğrafyada araştırılan olayların ele alınma biçiminde ve yapılan çalışmaların dilinde ne gibi değişimler yarattı/yaratmalı? Newton fiziğinin determinist ilkesi bu süreçte nasıl bir dönüşüm geçirdi? Coğrafyanın nedensellik ilkesi bu dönüşüm sürecinde nasıl konumlandırılabilir? gibi sorular çalışmanın hedeflerine ulaşmada referans noktası olarak kullanılacaktır.

\section{Kuantum Mekaniği}

Latince kökenli bir kelime olan kuantumun sözlük karşılığ "ne kadar" anlamına gelmektedir. Günümüzde kuantum kavramı, çok küçük enerji parçacıkları, atom ve atom altı parçacıkları için kullanılmaktadır. Sözcüğün çoğulu "kuanta"dır. Kuantum mekaniği ise atomdan daha küçük parçacıkların gücü ve hareketleri ile ilgilenen mekaniğin bir dalını oluşturmaktadır. Kuantum fiziğinde ise kuantum, mikroskobik düzeyde tahmin edilen ya da gözlemlenen belirli madde ve enerji parçacıkları olarak tanımlanmaktadır. Kuantum mekaniğinin gelişmesi 20. yüzyıl başlarına, Max Planck'ın çalışmalarına dek uzanmaktadır (Hendricks, 2015). Aslında kuantum mekaniği fizik içerisinde çok yeni bir alt disiplin gibi görülmesine karşın ilk ortaya çıkışı bir yüzyılı aşkın süreyi kapsamaktadır. Kuantum mekaniği, kuantum fiziği ve kuantum teorisi olmak üzere üç isim genellikle eş anlamlı olarak kullanılmasına karşın en yaygın ve kabul göreni kuantum mekaniğidir.

Kuantum mekaniği birçok hipotez, deney ve teoriyi içinde barındırmasına karşın bu hipotez, deney ve teorilerden elde edilen sonuçlar Einstein'ın izafiyet teorisi ve dolayısıyla makro fizikteki gerçeklikle uyumsuzluk göstermektedir. Yani makro düzeydeki klasik fizik ile mikro düzeydeki kuantum fiziği birbiri ile uyuşmamaktadır. Örneğin, kuantum fiziğinde Heisenberg Belirsizlik İlkesine göre bir atom altı parçacığın aynı anda konum ve hızı tam olarak belirlenememektedir. Elektronların (negatif yüklü atom altı parçacıkları) hızı ve konumu olasılıklı olarak belirlenebilir. Elektronlar sadece bir yörüngeden diğer bir yörüngeye atladıklarında/sıçradıklarında (quantum leap) gerçek olmaktadırlar (Rovelli, 2016).

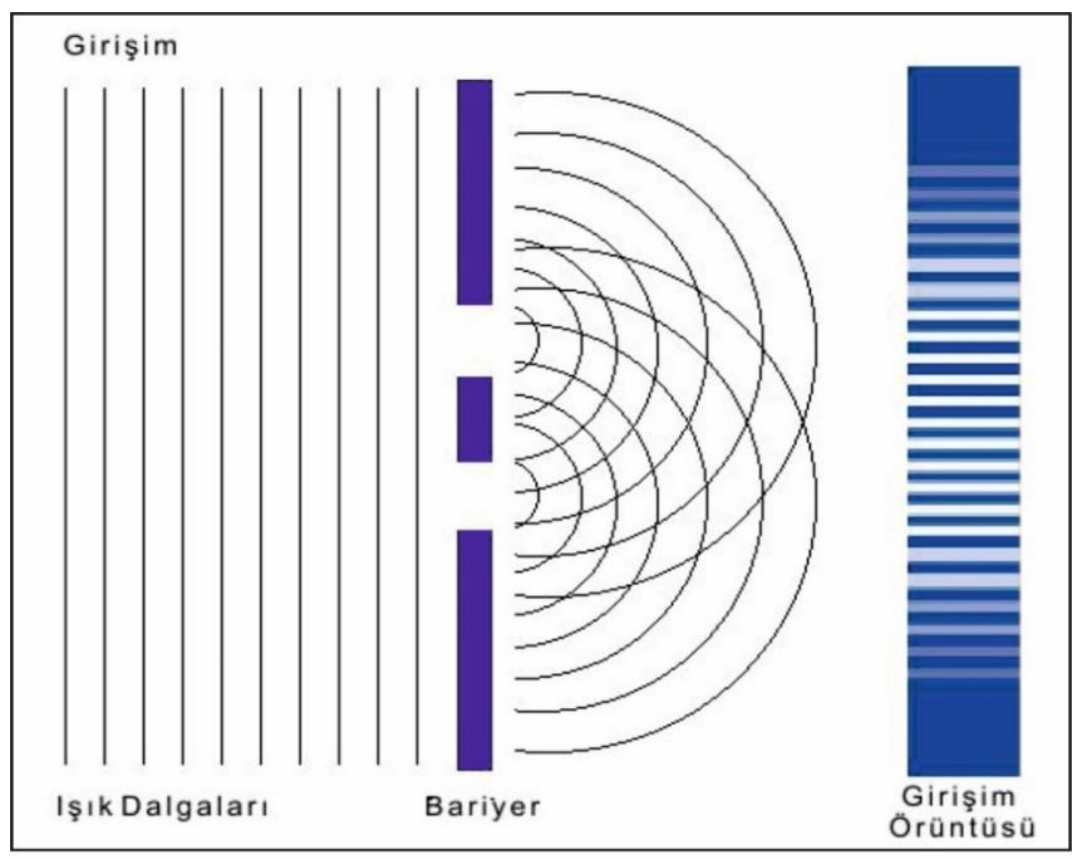

Şekil 1. T. Young'un çift yarık deneyi 
Şekil 1'deki deney, kuantum mekaniğinde defalarca yapılan çift yarık deneyidir (double slits experiment). Bu deney ilk defa 1801 yılında kuantum mekaniğin gelişiminden çok önce Thomas Young tarafından yapılmıştır. Bu deneyde bariyere tek yarık açıldığında ve o yarıktan elektronlar geçtiğinde parçacıklardan oluşan çizgi şeklinde bir girişim örüntüsü oluşmaktadır. Çift yarık açılıp elektronlar bu yarıklardan geçirildiğinde ise parçacıklardan oluşan iki girişim örüntüsü oluşmaktadır. Tam bu noktadan sonra deney şaşırtıcı bir duruma gelmektedir. Çünkü elektronları biri gözlemlediğinde ya da yerine gözlem yapan bir aygıt konulduğunda girişim örüntüsü parçacık değil dalga konumunu almaktadır (yukarıdaki şekilde girişim örüntüsü olarak adlandırılan yer) ve bu dalga boyları sadece iki tane ile sinırlı değildir. Yani onlarca dalgadan oluşan bir girişim örüntüsü meydana gelmektedir. Gönderilen ışık dalgaları hem dalga hem de parçacık özelliği göstermektedir. Gözlemlenmediğinde parçacık, gözlemlendiğinde neden dalga konumuna geldiği halen çözülememiştir (Hendricks, 2015).

Kuantum mekaniğindeki işleyişe getirilen açıklamaların en önemlilerinden biri Kopenhag Yorumudur. Kopenhag Yorumu (Kopenhag olarak adlandırılması Kopenhag Fizik Enstitüsünde yapılan çalışmalara atfen verilmiştir) 1925'li yıllarda ünlü fizikçiler Niels Bohr ve Werner Heisenberg' in çalışmalarına dayanmaktadır. Bu dönemde yapılan yorumlar halen geniş bir şekilde tartışılmaktadır. Kopenhag Yorumu'na göre fiziksel sistemler ölçüm yapılmadan önce kesin özelliklere sahip değillerdir. Kuantum mekaniğinde sadece ölçümlerin ortaya koyacağı olasılıklar belirlenebilir. Aynı zamanda ölçümün yapılması sistemleri etkilemekte ve olasılıkların ölçümden sonra bir kısmının azalmasını sağlamaktadır. (Faye, 2014). Yani ölçümün bizzat yapılması sonucu etkilemektedir. En azından ölçüm olasılıkları ve olasılıkların oranı üzerinde etkilidir. Kopenhag Yorumu, çoklu dünyalar teorisi gibi birçok teori ile karşı gelinmesine karşın getirdiği yorum sadece fiziği değil birazdan göreceğimiz birçok bilim dalını da fazlasıyla etkilemiştir.

Kuantum mekaniğinin gerçeklikle ilgili bir diğer problemi yerel olmama (nonlocality) olarak bilinmektedir. Yerel olmama, mikroskobik düzeyde yapılan ölçümlerin klasik mekanikte işleyen yerel gerçeklik (local realism) ile örtüşmemesi durumudur (Wendt, 2015). 1935 yılında Einstein, Podolsky ve Rosen yaptıkları çalışmada etkileşime giren kuantum parçacıklarının birbirine geçtiklerini ve dolanık olduklarını (entangled particle) ve ayrı olarak düşünülemeyeceğini belirtmişlerdir (Greene, 2007). Bell Eşitsizliğine (Bell Inequality) göre ise eğer deney ihlal ediliyorsa kuantum mekaniği ya yerel olmayı ya da gerçekliği ihlal etmektedir (Rae, 2005).

\section{Kuantum Mekaniği ve Sosyal Bilimler Felsefesi}

Gerçek nedir? Gerçeklik dediğimizde sadece maddeyi mi anlamalıyız? Sosyal gerçeklik nedir? Tek bir sosyal gerçeklik var mı? Sosyal gerçekliğe materyalistlerin dediği gibi maddeden/fiziksel işleyişten mi ulaşılır? Eğer her iki gerçekliği (fiziksel ve sosyal) kabul edersek -ki bilim insanlarının önemli çoğunluğu bunu kabul ediyor- bu iki gerçeklik bağdaşır mı? Kuantum mekaniği gerçekliği nasıl etkilemektedir? Klasik fizik ve kuantum fiziğinden ikisi de gerçekse hangisi daha gerçektir? İki gerçekliğin kesişmesi olası mıdır? Fen bilimleri ve bilim tarihinin ana omurgasını oluşturan ve en gerçek bilim olarak bilinen fizik içinde tek gerçeklik yoksa ve kuantum teorisi makro gerçekliğe baş döndürücü bir yönden yaklaşıyorsa sosyal alandaki gerçekliğin çok parçalı olması doğal değil midir? Klasik fizik ile kuantum fiziğin gerçekliğe farklı açılardan yaklaşması sosyal bilimleri nasıl etkilemektedir? Yoksa bilim, Thomas Kuhn'un dediği gibi sağlam bir temele oturmuyor mu? Bilimin ontolojisi yani bir anlamda gerçekliği nerede? Bu soruların bir kısmı yanıtlanmış veya yanıtlanmaya 
çalışılmış bir kısmının üzerinde ise henüz kesin bir uzlaşıya varılamamıştır. Kuantum mekaniğinin sosyal bilimler üzerindeki etkisi de daha çok bu sorular bağlaminda ele alınmaktadır. Gerçeklik, olasılık, determinizm, nedensellik, kesinlik, değişmezlik ve gözlem gibi kavramlar kuantum mekaniği ile tekrar gözden geçirilmeye başlanmıştır.

Gerçekliğin sorgulanmasının ana nedeni bilimin gerçeklikle örtüştüğü ya da gerçeğe en yakın bilginin bilimsel bilgi olduğuna olan güvendir. Bilginin en yaygın tanımı "gerekçelendirilmiş doğru inanç" olarak ifade edilmektedir (Nagel, 2014). Aslında bu tanım bile çeşitli itirazlarla karşılaşsa da en yaygın bilgi tanımı olarak durmaktadır. Bilimsel bilgi ise kuşkusuz bundan daha fazlasını içeriyor. Bilimsel bilgiyi diğer bilgi türlerinden ayıran özellikler nelerdir? Bir bilginin bilimsel bilgi olduğunu nasıl anlıyoruz? Bilimsel bilgi ve bilimsel açıklama ile bilimsel olmayan bilgi ve açıklamanın sınırı nedir? Woodward'ın (2014) dediği gibi eğer bilimsel açıklamadan bahsediyorsak bilimsel olmayan ve bilimsel açıklama sayılmayandan farkının ne olduğunun belirtilmesi gerekmektedir. Bir bilgiyi bilimsel bilgi yapan özelliklerden en önemlisi nedenselliğe dayanmasıdır. Yani olay, gerçek ve gözlemleri neden-sonuç bağlamında açıklayabilmesidir. Tanımlayıcı, betimleyici ve hikâyeci anlatımların bilimsel bilgideki yeri giderek sınırlanmıştır. Bilginin neden-sonuç bağlamında ele alınması, genel yargılara ulaşması, gerçek ya da gerçekliğe yakın olması, teorilerle desteklenmesi bilimsel bilginin en önemli özellikleri olarak durmaktadır.

Doğa bilimlerindeki determinizm§, sosyal bilimler içinde önemli bir yer edindi. Özellikle sosyal bilimler içinde determinizm, fen bilimlerine göre daha sert muhalefetle karşılaştı ve zamanla gözden düştü. Zira determinizmin önemli oranda özgür irade ile çeliştiği düşünülüyordu. Sosyal bilimlerin ana inceleme konusu insan ve onun faaliyetleridir. Bu faaliyetlerin çoğu insan iradesine dayanmaktadır. Determinizm ise kısaca; belirli bir zaman diliminde, belirli şartlar altında, belirli sonuçların zorunlu olarak ortaya çıkması olarak tanımlanmaktadır. Bu da gerekliliği (necessity) akla getirmektedir. Williams (2000), gerekliliği, bilimi ve onun keşiflerini destekleyen amaç olarak görmektedir. Ayrıca Laplace yeterli bir akıl ve ulaşılabilir bir bilgi ile evrendeki her şeyden emin olabilmenin mümkün olduğunu belirtmektedir (Williams, 2016). Ona göre evrenin şimdiki halini geçmişin sonucu ve geleceğin nedeni olarak ele alabiliriz. Deterministik bir yaklaşımı benimseyen Laplace olguların nedenleri bilinirse tüm sonuçların ve gelecekte neler olabileceğinin bilinebileceğini savunmaktadır. Hatta bu noktada Laplace, determinizmden tahmin edilebilir sonuçlara varılacağını düşünmektedir (Thompson, 2012).

Determinizmde bahsedilen şartlar daha çok doğal yasalar olarak düşünülmektedir. Kuantum mekaniği, determinizmin doğa bilimler içinde de gözden düşmesinde önemli oranda etkili oldu. Çünkü atom altı parçacıkları dünyasında bir parçacığın konumu ve hızı aynı anda kesin olarak belirlenemediği gibi, bu parçacıklar gözlem öncesi ve sonrası ile ilgili yapılan gözlemlerde kesin sonuç vermiyordu. Sadece belirli olasılıklar dizisi sunmaktaydı. Bu klasik fizikte karşılaşılan bir durum değildi. Aslında klasik fizik de tam olarak deterministik değildi. Çünkü çoğu zaman ceteris paribus (diğer tüm şartların sabit kabul edilmesi) ilkesi benimsenmiştir. Yani klasik fizik ve kimya doğal yasaları tam olarak işletmek ve bu yasaların eksiksiz olduğunu göstermek adına diğer şartların elimine edilmesini öngörüyordu. Yine kuantum mekaniği ve sosyal bilimlere olan etkisine dönecek olursak; kuantum mekaniğinin

§ Determinizm, uzun süre temel bilimsel program olarak kabul edilen Newton mekaniğinin en temel unsuruydu. Determnizm, temel kuramsal açıklamaların "bilimsel” olup olmadı̆̆ını belirlemeye yarayan bir dizi asgari kritere eklenmek üzere, doğrusallık, denge durumu ve tersinirlik ile birleştirilmişti (Wallerstein, 2013: 49). 
deterministik bakış açısına darbe vurması sosyal bilimlerde bu bakış açısına karşı olan duruşu kuvvetlendiren önemli unsurlardan biri oldu. Gelişme teorileri, modernizasyon teorisi, rasyonel seçim teorisi, Marksist teori, Rostow'un gelişme basamakları, Durkheim'ın sosyal teorisi sosyal bilimler içinde fazlaca deterministik bulunan teorilerdi. İnsanın özgür iradesini ikincil plana atan, bireyi daha mekanistik ve deterministik açıdan ele alan bu yaklaşım ve teoriler kuantum mekaniği bağlamında daha eleştirel düşünülmeye başlandı. En kuvvetli argümanlardan birisi; fiziki gerçeklik dahi deterministik değil ise insan iradesinin temelini oluşturduğu sosyal bilimler nasıl deterministik olabilirdi? Her ne kadar Hoefer (2016) kuantum mekaniğinin aslında deterministik olduğunu belirtse de bu mekaniğin deterministik olmadığı ve geniş bir olasılıklar ağı taşıdığ 1 genel kabul görmektedir.

Bilimin en vazgeçilmez özelliklerinden biri nedenselliktir. Bu özellik fen-sosyal bilimler ayrımı yapmaksızın bilimi bütüncül olarak etkileyen bir özelliktir, ancak nedenselliğin ne oranda etkili olduğu sosyal bilimler içinde daha tartışmalıdır. Sosyal bilimler içinde nedenselliğin ne olduğu ya da hangi nedenin hangi sonucu doğurduğu her zaman kesin netlikte belirlemek olanak dâhilinde değildir. Örneğin, Ruanda'da 1994 yılında yaşanan ve 800 bin kişinin öldürüldüğü katliamın nedenleri nelerdir? a) Ruanda Başbakanı'nın öldürülmesi b) Belçika koloniyalizminin etkileri c) Hutu-Tutsi kabileleri arasındaki gerilim d) Komşu ülkelerin müdahalesi. Sorun şu noktalarda başlıyor: Bu nedenlerden hangisi en etkilidir? Bütün nedenleri kapsayan her zaman ana bir neden var mıdır? Ya da anlık çıkan bir neden mi çatışmaya yol açmıştır? Benzer nedenler başka yerlerde aynı neden ve sonuçları doğurur mu? İndirgemeci bir yaklaşım nedensellik içinde ne kadar etkilidir? Bu soruların yanıtları sosyal bilimler içinde oldukça karmaşık ve çözümünün bir formüle dayanması imkânsız görünüyor. Zira insan iradesi onun her zaman belirlenemeyen davranışları birçok olgunun nedenini ve sonucunu oluşturuyor. Bu nedenle sosyal bilimler içinde her benzer olgu ve olayda temel oluşturacak nedenler ve sonuçlar aramak sonuçsuz görülebilmektedir. Çünkü insan davranışı üzerinden gitmek de gözden düşeli çok oldu. 20. yüzyılın ilk yarısında egemen olan davranış̧̧ılık bilişsel düzey yerine insan davranışlarından sonuca gidilebileceğini, olay ve olguların ancak böyle açıklanabileceğini düşünüyordu. İnsan konu olduğu için bu sistematik yaklaşım da doyurucu bulunmadı. Çünkü her istek, arzu, niyet, korku, inanç, başarı davranışlarla açılanamazdı. İnsan her durumda düşüncelerini, bilincini davranışlarına yansıtmıordu. Bu nedenle davranışçı temelli psikoloji, ekonomi, coğrafya, sosyoloji ve antropoloji gözden düştü. İnsanın karmaşık bir yapı olduğu bu yapıdan belirli olgular çıkarılabileceği ancak bilimsel yasa üretmenin çalışılan konu itibariyle zor olduğu konusunda genel bir uzlaşı olduğu görülüyor. Tüm evren, dünya, eşya ve insan atom ve atom altı parçalarından oluşuyor. Kuantum mekaniği atom altı parçacıklarının ne zaman sıçrayacağı, hangi durumda parçacık hangi durumda 1şık halinde olacağı sadece olasılıklar dâhilinde biliniyor. Yani kesin bir nedensellik yok, sadece olasılıklara dayalı tahmin bulunuyor. Oysa fizik nedenselliğin en kuvvetli şekilde görüldüğü bilim olarak görülüyor. Dolayısıyla saf hatta "hard" bilim statüsünü koruyan fizik içinde nedensellik tam olarak anlaşılamıyorsa ya da işlemiyorsa sosyal bilimlerde işlemesinin beklenmesi doğal mıdır? Atom altı parçacıkları tamamen olasılık ve tahmin içeriyorsa, insanın da tamamen bu parçacıkların oluşturduğu bir yaşam formu olduğu düşünüldüğ̈̈nde nedensellik tam olarak nasıl işleyebilir?

\section{Kuantum Mekaniği ve Coğrafya}

Coğrafyanın üzerinde geniş uzlaşı sağlanmış kısa ve klasik bir tanımı bulunuyor. "Coğrafya, insan ve çevre arasındaki karşılıklı etkileşimi inceler. Bu karşılıklı ilişki yaklaşımına Antik 
Dönem'de de rastlanmaktadır. Hipokratus'un (M. Ö. 460-377) yaptığ çalışmalarda çevrenin insan üzerinde etkili olduğu bilinmekteydi. Buna göre insanlık tarihi boyunca gelişen ve 19 . yüzyılda kurumsallaşan coğrafya, diğer sosyal bilimlere göre daha köklü bir determinist geleneğe sahiptir. Coğrafya, 19. yüzyılda Alman üniversitelerinde bir bilim alanı olarak kurumsallaşmaya başlamıştır. Bu dönemde C. Darwin'in “Türlerin Kökeni” (1859) kitabı yayımlanmıştır. Yarattığı tartışma ve etkilerle etkisi günümüze kadar süren bu kitap, dönemin bilimsel çalışmalarını derinden etkilemiştir. Coğrafya da bu etkilerden payına düşeni almış ve çevresel determinizm bu dönemde yapılan coğrafi çalışmalara damga vurmuştur [F. Ratzel (1844-1904), E. C. Semple (1863-1932) E. Huntington (1876-1947)]. Aynı dönemde P. V. de La Blache (1845-1918) öncülüğünde bölgesel gelenek de coğrafya içinde ana akım bir gelenek olarak kurumsallaşmaya başlamıştır. 1950'lerde kantitatif devrimi yaşayan coğrafya 1970'lerde doruğa çıkan eleştiriler sonunda çoklu paradigma dönemine geçmiştir (Şekil 2). Bu çalışmanın amacı, doğrudan coğrafyadaki paradigma değişimleri olmadığından bu konuda ayrıntıya girilmeyecektir.

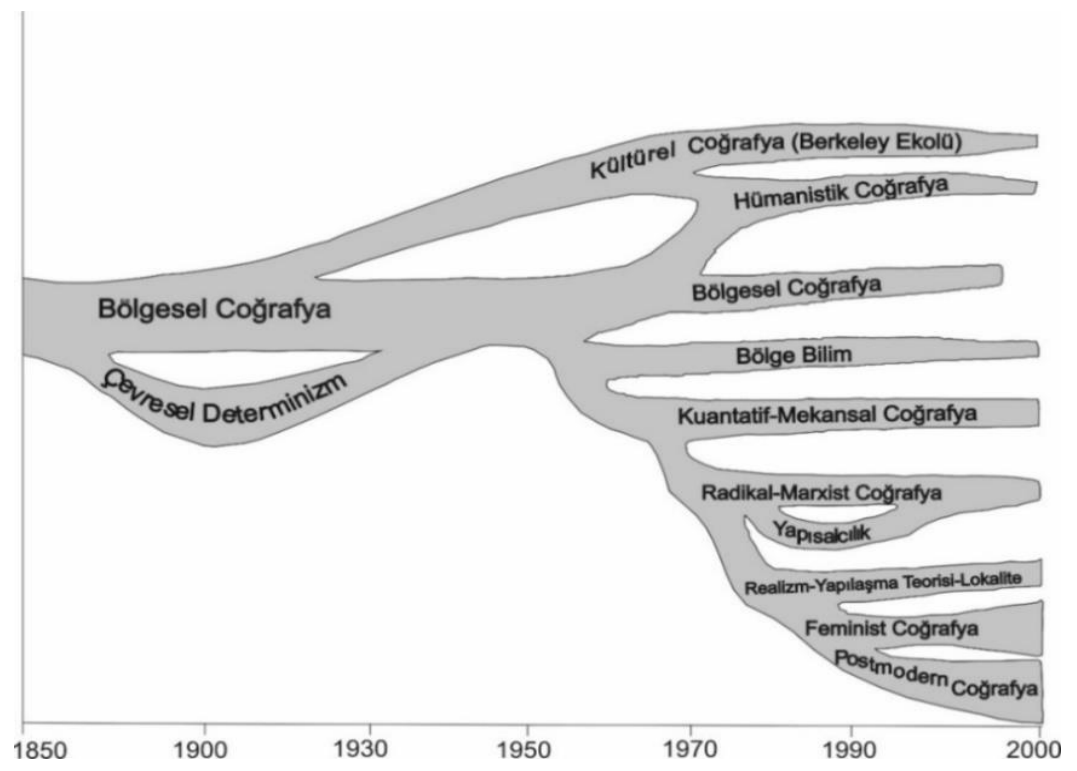

Şekil 2. Coğrafi düşüncenin gelişimi (Peet, 1998)

Günümüzde coğrafya disiplini sosyal bilimler çatısı altındadır. Coğrafya, beşeri ve fiziki coğrafya olmak üzere iki temel anabilim dalından oluşmaktadır. Fiziki coğrafya ile doğa bilimleri, beşeri coğrafya ile sosyal bilimlere yakınlık kuran coğrafya, doğa bilimleri ile sosyal bilimlerin kesişme alanında faaliyet göstermektedir. Bu haliyle coğrafya, üyesi olduğu sosyal bilimler çatısı altındaki diğer disiplinlere göre doğa bilimleri ile farklı bir ilişki kurmuştur. Söz konu yapıdan dolayı, paradigma değişimleri coğrafyanın bu ikili yapısına göre şekillenmiştir. Fiziki coğrafyanın doğa bilimlerine olan yakınlığı ve yıllarca süren disiplin içindeki hakim konumundan (yer bilimleri geleneği) dolayı coğrafya, disiplin olarak doğa bilimlerinden doğrudan etkilenmiştir. Doğa bilimleri ile doğrudan ilişkili olan fiziki coğrafyanın uzun dönem disiplini domine etmesi sebebiyle doğa bilimlerinin coğrafya üzerindeki etkisi oldukça belirgindir. Deyim yerindeyse fiziki coğrafya, coğrafya disiplini içinde adeta doğa bilimlerinin bir "ajanı" olarak konumlanmıştır.

1970'lerde yaşanan felsefi açılımlar diğer sosyal bilimler gibi coğrafyada da ontolojik ve epistemolojik sorgulamalara yol açmıştır. Çok paradigmalı bu dönemde coğrafyanın geleneksel paradigması olan bölgesel coğrafya ve özellikle çevre koşullarının insanın 
faaliyetlerini belirlediğini savunan çevresel determinist görüş eleştirilmiştir. İnsan, çevrenin bir parçası hatta onun ta kendisi değil mi? İnsanı çevreden soyutlayan, yalıtılmış şekilde gösteren geleneksel coğrafya tanımında insan çevreden bağımsız gibi algılanmıyor mu? gibi sorular çevresel determinist yaklaşıma yönelik eleştirilerin temelini oluşturmuştur. Çevresel determinizmin genel olarak etkisini yitirdiği söylenebilir. Coğrafyacılar Ernste ve Philo (2009), fiziğin bile klasik (Newtoncu) fizikten izafiyete oradan da kuantum fiziğine geçip belirsizliği (uncertainity) kabul ettiğini bu yüzden de determinizme karşı mesafeli olunması gerektiğini belirtmiştir. Ancak bu yadsımalara rağmen coğrafi disiplin içinde bazı makale ya da kitaplarda determinist görüşe ait izlere hala rastlanmaktadır.

Çevresel determinist görüşe göre birbirine karşı iki ayrı kategori olarak ele alınan çevre ve insan yaklaşımı şu sorularla eleştirilebilir: "insan çevrenin bir parçası hatta onun ta kendisi değil mi? İnsanı çevreden soyutlayan, yalıtılmış şekilde gösteren bu tanımda insan çevreden bağımsız gibi algılanmıyor mu? Fizikçi Rovelli uzayın boşluktan ibaret olmadığını atom ve atom altı parçacıkları ile dolu olduğunu ve insanın bu uzayın kendisi olduğunu vurguluyor (Rovelli, 2016). Bu coğrafyanın ana paradigması mekân ile neredeyse tam olarak örtüşüyor. Günümüz mekânı da canlı, genişleyen, üretilen, bükülen ve sürekli tüketilen ve yeniden üretilen bir süreç. Çünkü süreç sonlu değil; nereye gittiğini ve sonlanıp sonlanmayacağ konusunda kesin bilgilerimiz bulunmuyor. Sadece tahminler ve düşünce deneyleri var. Uzay ve bir anlamıyla içini doldurduğumuz anlam verdiğimiz coğrafi mekân dümdüz değil eğiliyor ve kıvriliyor.

Hipotez ortaya atma, teorik altyapı ve model oluşturma gibi bilimsel çalışmaların gerçek olmadığı ancak gözlemlenen olgulardan, gözlemleyemediğimiz olgular hakkında bilgi ve öngörü gücümüzün artmasına yaradığı şeklindeki yaklaşım bilim felsefesinde araçsallık (instrumentalism) olarak bilinmektedir. Realistler genel olarak bu bakış açısını paylaşmamalarına karşın rasyonalistler arasında biraz daha kabul görmektedir. En önemli temsilcileri ise John Dewey ve Karl Popper olan araçsallık, bu tür girişimleri bilimsel gerçeğe ulaşmanın aracı olarak görmektedir. Popper (2015) bilim, insan fikirlerinin üretim sistemidir: Buraya kadar idealizm haklıdır. Ancak bu fikirler olasılıklar karşısında başarısızlığa uğrayabilir. Bu yüzden sonuç olarak realizm haklıdır demektedir. Gerçekliğe yaklaşımı rasyonalist ve realist bir temele oturmaktadır. Kuantum mekaniğinin gelişme tarihinde önemli yeri olan Kopenhag Yorumunda ise gerçekliğin ne olduğundan ziyade gerçekliğin nasıl tanımlanabileceği üzerinde yoğunlaşılmıştır. Gerçeklik, yani ontolojiden ziyade epistemoloji üzerinde durulmuştur. Gözlenen-gözlemci arasındaki ayrımın kuantum mekaniğinde yıkılması, gerçekliğin ne olduğunun sorgulanmasına yol açtı. Bohr'un kuantum gerçekliğini sorgulaması realist bakış açısının da sorgulanmasına yol açtı. Bu bakış açısı rölativist ve postmodernistlere destekleyici kanıt oluşturdu (Wendt, 2015). Sosyal bilimler ve dolayısıyla coğrafya, kuantum mekaniğinin bilimsel bakış açısından etkilendi. Coğrafya içinde feminist coğrafya, postkoloniyal coğrafya, eleştirel beşeri coğrafya, postmodern coğrafya gibi birçok yaklaşımın gerçekliğe olan bakışında kuantum şekillendirici etkenlerden biri oldu. Çünkü tek ve kesin gerçeklik yoktu. Gerçekliğin temeli sorgulanmaktaydı. Böylece katı bir gerçeklik algısından yola çıkan pozitivizm de doğal olarak gözden düştü. Gerçekliğin bağlamsal olabileceği, insan iradesi, katı yapısalcılığın terk edilişi kuantum mekaniği ile daha da ana akım düşünce sistemlerine dönüştü. Kuantum mekaniğinde gözlemci etkisi (observer effect), yani gözlemcinin gözlenenden ayrı düşünülemeyeceği de sosyal bilimlere sağlam bir argüman sağladı. Birçok nitel araştırma metodunda gözlemcinin, gözlenenden ayrı düşünülemeyeceği, araştırmacının araştırmanın parçası olduğu, hatta araştırmacının dönüştürücü etkiye sahip 
olabileceği vurgulanmaya başlanmıştır. Yapılandırmacı ve yorumlayıcı metotlar gerçekliğin çoklu olduğu, bağlamın göz ardı edilemeyeceği, değişmez bir temel olmadığı konusunda birleşmiştir. Eleştirel (critical) ve dönüşümcü (transformative) yaklaşımlar ise bir adım daha ileri giderek araştırmacının sosyal bilimlerde sadece gözlemci değil, bizzat katılımcı ve dönüştürücü etkisi üzerine yoğunlaşmıştır. Gözlemci, yani araştırmacı artık çalışmayı uzaktan izleyen konumda değil araştırmanın tam merkezine yerleşmiştir.

Harrison ve Dunham (1998) jeomorfoloji felsefesi içinde kuantum mekaniği yaklaşımının benimsenmesi yönünde normatif bir yaklaşım öne sürmektedir. Bu yaklaşımlarını üç argüman ile destekliyorlar. "Birincisi, Kopenhag Yorumu kuantum mekaniği ile bilinç, farkındalık ve jeomorfolojik manzara arasındaki ilişkisellik daha net bir şekilde ortaya konur. Böylece idealist yaklaşımın gerçeklik algısı, realist veya ampirik yaklaşıma oranla daha iyi verilir. İkincisi, realist ve ampirik yaklaşım ile kuantum bileşenleri arasındaki uyumsuzluk (quantum decoherence) ve gözlemcinin gözlenenden kesin olarak ayrı olması gibi özellikleri çok iyi açıklanamaz. Üçüncüsü, kuantum mekaniği, jeomorfoloji içindeki belirsizlikleri ve olasılıkları açıklamada lineer olmayan dinamikleri ve olasılıklı sistem teorilerini açıklamaya yarayan alternatif fikirler seti sağlayabilir". Çalışmada jeomorfolojide yeni paradigmalara yer olması gerektiği belirtilirken, kuantum mekaniğinin coğrafi disiplinde sadece beşeri coğrafya alt dalının yanında fiziki coğrafya içinde de yer bulabildiği görülmektedir.

Ünlü coğrafyacı Doreen Massey (1999), coğrafyacıların genel olarak doğa bilimlerini özellikle fiziği, bilimsel model olarak düşündükleri için bu alanda yaşanan gelişmelere kayıtsız kalamadıklarını belirtmiştir. Massey, fiziğin daha "sert" bilim göründüğünü ve coğrafyacıların yaklaşımlarını harekete geçiren dürtüyü bir anlamda fizikte bulduklarına değinmiştir. Massey ayrıca kültürel coğrafyacıların kaos teorisi, şehir teorisyenlerinin modeller için kuantum mekaniği, bilginin doğasının ne olduğunu araştıran herhangi birinin Heisenberg'in düşüncesinden yararlanabileceğini vurgulamıştır. Massey, konuya bazı açılardan eleştirel bir yaklaşım da sergilerken şöyle diyor; “...bugünlerde çokça fiziğe başvurulmasının temel nedenleri kuantum mekaniği bağlamında dünya hakkında yeni görüşlerin ortaya çıkması ve son gelişmelerdir. Bu yaklaşım, yeni fikirleri harekete geçirmesi şeklinde referans olarak alınırsa kabul edilebilir. Ancak bu yüksek bir otoriteden kanıt alındığının göstergesi şeklini aldığında esas ironi bu otoritenin yani şimdiki fiziğin aslında fiziğin çok eski bir formuna göre konumlandığı ve yerleştiği bilinmelidir. O halde referanslarımızın statüsü ve doğası hakkında tedbirli olmamız gereklidir..."Massey açıkça fizik ve kuantum fiziğini, coğrafyayı daha bilimsel göstermek amacıyla kullanmamıza gerek olmadığını, ancak ilgili disiplindeki bize ilham veren ve yeni yaklaşımlara ulaşmamızı sağlayan araçlar olarak görmemizin daha doğru olacağını belirtmektedir.

Coğrafya içinde pozitivist yaklaşım, kabaca 1950-1960 arası oldukça etkili oldu (Bennett, 2009). $\mathrm{Bu}$ dönemde sadece coğrafya değil psikoloji, ekonomi gibi diğer sosyal bilimler de pozitivizmden oldukça etkilendi. Bu gelişmeler coğrafya içinde bu dönemde etkili olan Nicel Devrimin ve onunla yakından ilgili olan daha statik mekânsal algının etkisini yitirmesine neden oldu. Yani fizikte yaşanan gelişmeler doğrudan ya da dolaylı olarak coğrafyada paradigma değişikliğine yol açtı.

Biggs (1987), Kuantum Teorisi ve Coğrafya (Quantum Theory and Geography) adlı kısa çalışmasında Newtoncu düşünce sisteminde büyük olayların büyük sonuçlar gerektirdiğini düşünüldüğünü ancak kuantum teorisinde çok küçük değiş̧enlerin bile büyük değişimlere yol açabileceğini vurgulamaktadır. Biggs ayrıca coğrafyacıların olay örüntülerinin analizi ve 
sistemlerin gelişimleri konusunda kuantum teorisinden yararlanmadıkları sürece yapılan açılamaların eksik kalacağını söylemektedir. Peterman (1994) ise makalesinde coğrafyada yaşanan düşünce değişimleri ile kuantum mekaniği arasında bir bağ kurmuştur. Ona göre 1960'lı yıllardan sonra coğrafyada kantitatif ve pozitivist anlayışın terk edilmesi ve yerini hümanist odaklı yaklaşımlara bırakması bütün coğrafyacıları memnun etmemişti. Peterman, coğrafyanın bu yıllarda (60 ve 70li yıllar) yaşadığı pozitivist-hümanist yaklaşımların orta yerinde coğrafyada kuantum mekaniğine yer olduğunu vurgulamıştır. Kuantum mekaniğindeki belirsizlik, bütüncüllük, özne-nesne ilişkisi gibi temel kavramlar hümanistik coğrafyada da önemli yer bulan kavramlardır. Peterman ayrıca anlamın sadece belirli bağlamlarda bilinebileceğini ve bu anlayışın kuantum mekaniği ile hümanistik coğrafyanın paylaştığı ortak yaklaşım olarak görmektedir. Sorensen (2013) ise ilk bakışta ekonomi ve toplum ile parçacık fiziğinin hiçbir şekilde birbirine benzemediğini düşünebileceğimizi ancak kuantum mekaniğindeki fikirlerin coğrafya, ekonomi ve sosyolojiye uyarlanması üzerine geniş bir literatürün olduğunu belirtiyor.

Sosyal bilimleri ve dolayısıyla coğrafyayı yakından ilgilendiren bir diğer teori de etkileri itibariyle kuantum mekaniğini çağrıştırmakta ve benzer olgulara atıf yapmaktadır. Bu teori sistem teorisi olarak bilinmektedir. 20. yüzyıl ortalarında ortaya çıkan sistem teorisi tek bir teoriden oluşmamaktadır. Birçok disiplinin yararlandığı sistem teorisine göre bir sistem sadece parçalarının toplamı değildir ve daha fazlasını içermektedir. Önemli olan bir sistemde parçaların birbirini etkilemesiyle ortaya nasıl bir sonucun çıktığıdır. Dolayısıyla sistem teorisi indirgemeci (reductionist) değildir. Örneğin, kaos teorisi, karmaşıklık (complexity) gibi teori ve yaklaşımlar çoğunlukla sistemlerin incelenmesini gerektirir. Sadece sistemin parçalarından sonuca ulaşmak kolay değildir. Sosyal bilimler insan iradesini barındırdığı için çok daha kompleks sistemleri içerir. Sistem teorisi de önemli oranda kuantum fiziğinden etkilenmiştir. Çünkü gerçekliği daha çok ilişkisel olarak ele aldığı gibi parçalardan çok sistemin nasıl sonuç verdiği üzerinden ilerlemektedir. Benzer şekilde coğrafya da bu yaklaşımlardan etkilendi. Noel Castree (2005) "Coğrafya bilim mi?" adlı makalesinde birçok fiziki coğrafyacının doğadaki karmaşıklık, düzensizlik ve ihtimallerle daha fazla ilgilenmeye başladığını belirtmektedir. Aynı şekilde Stephan Harrison (2005) karmaşıklık teorisi, kaos teorisi ve kuantum mekaniğinin çevresel sistemlerin nasıl işlediği konusunda coğrafyaya ilham verdiğini söylerken, fiziki coğrafyacıların bu sistemlerin doğru ve objektif bir şekilde nasıl ele alınacağı konusunda sınıflandırma, gözlem ve ölçüme bağlı kaldıklarını vurgulamaktadır.

\section{Sonuç}

Sosyal bilimler veya coğrafya kuantum mekaniğine neden yoğun ilgi gösteriyor? Sosyal bilimcilerin ve coğrafyacıların kuantum mekaniğinde aradıkları tam olarak nedir? Kuantum mekaniği, en azından dışarıdan bir gözlemci ve okuyucu için gizemli, mistik, bilinen ve bilinmeyenin iç içe geçtiği bir mekanizma olarak duruyor. Fizikçiler, bu mekaniğin gizemli gibi sıfatlarla anılmasından rahatsız olabilirler ve sadece açıklanamayan olgu ve gerçekler olduğunu söyleyebilirler ancak bu yine de var olan imajı ve algıyı ortadan kaldırmıyor. Çünkü gerçekliğin madde olduğuna ve her şeyin madde ile açıklanabileceğine dair materyalist yaklaşıma ters gelebilecek yorumları içeriyor. İnsan iradesi ve bilincini ön plana çıkaran idealistler gerçekliği madde dışında arıyorlar. Hatta kuantum mekaniğinde ve işleyişinde Tanrı'yı arayanlar da bulunmaktadır. Yani kuantum herkes için bir delil veya argüman sunma kapasitesine sahiptir. Dolayısıyla kuantum mekaniğine her disiplinden farklı yaklaşımlar 
olacaktır. Bu yaklaşımların ortaya çıkmasında kuantum mekaniğinde henüz tam olarak açıklanamayan birçok olgu ve işleyişin varlığının etkisi büyüktür.

Sosyal bilimlerin, fen bilimlerinden etkilenmesi ve zaman zaman onu taklit etmesi bir sır değil. Çalışmamızda kuantum mekaniğinin sosyal bilimleri ve coğrafyayı nasıl etkilediğini açıklamaya çalıştık. Ancak sosyal bilimler ve coğrafyada yaşanan paradigma değişimlerinin tek sebebinin kuantum mekaniği olduğunu iddia etmiyoruz. Yaşanan dönüşümlerde kuantum mekaniğinin, yön veren önemli bir etken olduğunu düşünüyoruz. Fen bilimlerindeki birçok kavram ve terimi sosyal bilimlerdeki kavramları açıklamaya yardımcı olmak için kullanıyoruz. Açıklanamayan ya da tam olarak açıklık getiremediğimiz olguları başka kavramlar üzerinden açıklıyoruz. Bu yaklaşım işlerlik kazandırma (operationalization) olarak adlandırılmaktadır. Örneğin, kuantum mekaniğindeki olasılık, karmaşıklık, yerel olmama kavramlarını, sosyal hayata ve orada yaşanan gerçeklikleri açılamak için kullanabiliyoruz. İklim değişimleri, tahminler ve sosyal olaylardaki öngörülerde çoğunlukla kuantum kavramlarından faydalanabiliyor ya da bilimsel analoji ithal ediyoruz. En azından kuantum mekaniğinde olasılığın güçlü bir yaklaşım olması insanın özgür iradesinin yer aldığı sosyal bilimlerdeki anlayış ile kolayca örtüşebiliyor. Bazen ise fen bilimlerindeki kavramları sosyal bilimlerde işlerlik kazandırmaktan çok argümanlarımızı kuvvetlendirmek için kullanabiliyoruz. Doğa bilimciler, sosyal bilimcilerin doğa bilimlerindeki gelişmeleri sosyal bilimlere yanlış aktarıp, yorumladıklarını sıklıkla dillendiriyorlar. Elbette bu serzenişte haklılık payı bulunuyor. Bu noktada vurgulamak istediğimiz nokta, sosyal bilimler her zaman fen bilimlerindeki kavram ve teorileri tıpa tıp alıp kullanmadıklarıdır. Bu kavramlara farklı anlamlar yükleyip farklı bağlamlarda kullanabiliyorlar. Örneğin, kuantum mekaniğindeki karmaşıklık rahatlıkla sistem teorisi ve kaos teorisini açıklarken kullanılabiliyor.

Sosyal bilimler ve coğrafyada kullanılan dilde önemli değişimler yaşanmıştır. Dil, gerçekliği aktaran bir araç mı? Yoksa bilimde kullandığımız teorik dil yardımıyla gerçekliği ya da gerçekliğin bir kısmını biz mi oluşturuyoruz? Dil ile aktarılmadığı sürece gerçeklik yok mu? $\mathrm{Bu}$ konuda en etkili yaklaşımı Ludwig Wittegenstein uzun yıllar önce ortaya koymuştur. Wittegenstein (1953), bir şeyi isimlendirmenin onu etiketlemeye benzediğini söylerken aslında dil ile gerçekliğin nasıl iç içe geçtiğini de göstermektedir. Neopozitivist Hans Reichenbach, kuantum mekaniği ile ilgili olarak fiziksel dünyanın yapısından ziyade dilin yapısının konuşulması gerektiğini belirtmiştir. Yani aslında sorunun gerçeklik değil, kuantum mekaniğinde kullanılan nötr dil, dalga dili ve parçacık dillerinin kullanılmasından kaynaklanan sorunlar olduğunu dile getirmektedir. Ona göre, kuantum mekaniğinin dili farklı versiyonlarda tekrar formüle edilebilir (Reichenbach, 1944). Einstein ve birçok kuantum teorisyeni gözlemlerimizin teorik yüklü olduğunu belirtmiştir. Dolayısıyla gerçekliğin bir kısmı teorik dil ile şekilleniyor ve ona göre anlam kazanıyor. Gözlemler teori ve kullandığımız dil ile yüklü ve onun dışına çıkamıyoruz. Belki de istesek de çıkamayız çünkü sosyal bir ortamın parçası ve ona gömülü bir şekilde yaşıyoruz. Bu yine de bizim dışımızda bilimsel bir gerçekliğin olmadığı anlamına gelmiyor, ancak bu gerçekliğe ulaşmanın kolay olduğu anlamina da gelmiyor. Bu nedenle kuantum mekaniği daha genelde fen ve sosyal bilimler teorik dil ile yüklü. Yani gerçeklik saf haliyle görünür olmanın oldukça ötesinde konumlanmış görünüyor. 


\section{Kaynakça}

Anlı, Ö. F. (2016). Bilim Savaşları, Modern Bilim İmgesinin Dönüşümü. Ankara: Phoenix Yayınevi.

Biggs, R. A. (1987). Quantum Theory and Geography. Earth Surface Process. Landforms 12 (5): 571-573.

Castree, N. (2005). Is Geography a Science? Questioning Geography: Fundamental Debates. Ed. Noel Castree, Alisdair Rogers \& Douglas Sherman. Oxford: Blackwell Publishing. 57-79

Ernste, H. \& Philo, C. (2009). Determinism/Environmental Determinism. International Encyclopedia of Human Geography.Ed. Rob Kitchin and Nigel Thrift. London: Elsevier. 102110.

Faye, J. (2014). Copenhagen Interpretation of Quantum Mechanics. The Stanford Encyclopedia of Philosophy Ed. Edward N. Zalta, Uri Nodelman, Colin Allen, Lanier Anderson.

Greene, B. (2007). The Fabric of the Cosmos: Space, Time, and the Texture of Reality. Knopf Doubleday Publishing Group.

Gülbenkian Komisyonu (2009). Sosyal Bilimleri Açın. Sosyal Bilimlerin Yeniden Yapılanması Üzerine Rapor. Çev. Şirin Tekeli. İstanbul: Metis Yayınları.

Harrison, S. \& Dunham P. (1998). Decoherence, Quantum Theory and Their Implications for the Philosophy of Geomorphology. Transactions of the Institute of British Geographers, 23, 501514.

Harrison, S. (2005). What Kind of Science Physical Geography? Questioning Geography: Fundamental Debates. Ed Noel Castree, \& Alisdair Rogers \& Douglas Sherman. Oxford: Blackwell Publishing.

Hendricks, J. (2015). Quantum Physics: Beginner's Guide to the Most Amazing Physics Theories, 3rd Edition, Kindle Edition.

Hickey, J. T. (2012). Philosophy of Science: An Introduction. Londra: Cambridge University Press.

Hoefer, C. (2016). Causal Determinism. The Stanford Encyclopedia of Philosophy. Ed Edward N. Zalta.

Massey, D. (1999). Space-time, Science and the Relationship between Physical Geography and Human Geography. Transactions of the Institute of British Geographers 24: 261-279.

Nagel, J. (2014). Knowledge: A Very Short Introduction. OUP Oxford.

Northrop, F. S. C. (1958). Introduction. Physics and Philosophy, the Revolution in Modern Science. Ed. Werner Heisenber. Londra: George Allen \& Unwin LTD. 11-31

Özgüç, N. \& Tümertekin, E. (2000). Coğrafya: Geçmiş, Kavramlar, Coğrafyacılar. İstanbul: Çantay Kitabevi.

Peet, R. (1998). Modern Geographical Thought. Oxford: Wiley-Blackwell

Peterman, W. (1994). Quantum Theory and Geography: What Can Dr. Bertlmann Teach Us? Professional Geographer 46 ( 1): 1-9.

Popper, K. (2015). Hayat Problem Çözmektir-Bilgi, Tarih ve Politika Üzerine. Çev. Ali Nalbant. İstanbul: Yapı Kredi Yayınları. 
Rae, A. (2005). Quantum Physics: A Beginner's Guide. Oxford: Oneworld Publications.

Reichenbach, H. (1944). Philosophic Foundations of Quantum Mechanics. Los Angeles: University of California Press

Rovelli, C. (2016). Seven Brief Lessons on Physics. New York. Penguin Publishing Group.

Skirbekk, G. \& Gilje, N. (2014). Antik Yunan'dan Modern Döneme Felsefe Tarihi. Çev. Emrah Akbaş \& Şule Mutlu. İstanbul: Kesit Yayınları.

Sorensen, T. (2013). Quantum Dreaming: The Relevance of Quantum Mechanics to Geography and Sustainable Systems. The Sustainability of Rural Systems Global and Local Challenges and Opportunities Ed. Mary Cawley, Ana Maria de S. M. Bicalho \& Lucette Laurens. Ireland: National University of Ireland Galway. 269-280

Thompson, M. (2012). Philosophy of Science: Teach Yourself. Hodder \& Stoughton.

Toffler, A. (1998). Takdim: Bilim ve Değişme. Kaostan Düzene. Ed. Ilya Prigogine \& Isabelle Stengers. İstanbul: İz Yayıncılık, 2. Baskı. 9-26

Woodward, J. (2014). Scientific Explanation. The Stanford Encyclopedia of Philosophy. Ed. Edward N. Zalta.

Wallerstein, I. (2013). Bilginin Belirsizlikleri. Çev. Berivan Alataş. İstanbul: Sümer Yayıncılık.

Wendt, A. (2015). Quantum Mind and Social Science: Unifying Physical and Social Ontology. Cambridge: Cambridge University Press.

Williams, M. (2000). Science and Social Science: An introduction. London: Routledge.

Williams, M. (2016). Key Concepts in the Philosophy of Social Research. London: SAGE Publications.

Wittgenstein, L. (1953). Philosophical Investigations. Çev. G. E. M. Anscombe. New York: Macmillan. http://abyss.uoregon.edu/ js/21st_century_science/lectures/lec13.html (16 Ocak 2017' de erişildi). 